\title{
PHYSICOCHEMICAL AND BIOLOGICAL WATER QUALITY ASSESSMENT OF THE GUEBLI RIVER, NORTHEASTERN ALGERIA
}

\author{
K. Boudeffa ${ }^{1, *}$, F. Fekrache ${ }^{1}$ and N. Bouchareb ${ }^{2}$ \\ ${ }^{1}$ Department of Nature and Life Sciences. Faculty of Sciences. August $20^{\text {th }}, 1955$ University of \\ Skikda, 21000, Algeria \\ ${ }^{2}$ Department of Biology, Abdelhafid Boussouf University Center of Mila, 43000, Algeria \\ *E-mail: k.boudeffa@univ-skikda.dz
}

\begin{abstract}
This study aimed to evaluate the quality of the water in the Guebli River. Five sampling stations were selected along the river to determine the important physicochemical and biological parameters of the water. Our results show that water from the downstream station is highly polluted because it has high levels of most physicochemical parameters compared to other stations. This situation may be due to the accumulation of waste discharged by human activities along the river. The study also shows that the least polluted stations have a very varied faunal structure compared to polluted stations.
\end{abstract}

Keywords: River, Water Quality, Physicochemical Parameters, Pollution, Algeria.

(c) RASĀYAN. All rights reserved

\section{INTRODUCTION}

Water is the first mineral resource in the world that is crucial for the survival of humanity, animal and plant kingdom. ${ }^{1}$ In recent years, human activity has considerably changed the physicochemical quality of water in our Mediterranean region. ${ }^{2}$ This situation is due to the introduction of important mineral and organic pollutants from agricultural (fertilizer), industrial and domestic discharges. ${ }^{3}$ These pollutants pose risks to aquatic ecosystems and associated biodiversity. They reduce the volumes of clean water available to people and also cause disease, eutrophication in the water reserves and affects ecological balance. ${ }^{4}$

Water quality assessment is often carried out using "classical" methods that measure a series of physicochemical parameters and then compared with proven standards. This approach has shown they're usefulness but also has its limitations. ${ }^{5}$

To measure the effects of water pollution, the classical approach (physicochemical parameters) can be complemented by biological monitoring that consists of using living organisms (biological indicators: e.g. Microorganisms, Plants or Animals). Among these indicators, the macroinvertebrates that are at the basis of different biotic indices (e.g. Standardized Global Biological Index, taxa richness, equitability, total abundance, Simpson Diversity Index) and are the subject of several hydrobiological studies. ${ }^{6,7,8}$ Indeed, the notion of ecosystem integrity or health requires simultaneous consideration of chemical, physical and biological parameters. ${ }^{9}$

Guebli River is one of the important rivers in the northeastern of Algeria. This watercourse is characterized by an intense anthropic influence manifested by agricultural activities practiced throughout the catchment area and by various activities related to the agglomerations installed along the river (Cities and villages). Information is not available on the water quality of this river used for domestic purpose, aquatic animals as well as agriculture activities. Our study aims to determine the values of major physicochemical and biological parameters in order to assess the quality of the water and to establish a comparison with the World Health Organization standards for drinking water.

Rasayan J. Chem., 13(1), 168-176(2020)

http://dx.doi.org/10.31788/RJC.2020.1315255

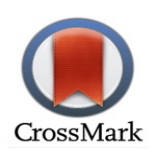


RASĀYAN J. Chem.

Vol. 13 | No. 1 |168 - 176| January - March | 2020

\section{Study Area and Site Description}

\section{EXPERIMENTAL}

The study was carried out in the Gubeli River which is the main river of the small independent coastal basins of eastern Algeria. The Guebli River drainage basin (catchment) is located in the north-west of the Skikda department (northeastern of Algeria) and extends from 6 $6^{\circ} 3^{\prime}$ to $6^{\circ} 47^{\prime}$ east longitudes and from $36^{\circ} 35^{\prime}$ to $36^{\circ} 58^{\prime}$ north latitudes. It covers an area of $993 \mathrm{~km}^{2}$ (Fig.-1). ${ }^{10}$ It belongs to the Mediterranean zone with a mean annual temperature of $19.0^{\circ} \mathrm{C}$ and a rainfall average reaches of $813 \mathrm{~mm}$.

Five sites were selected and sampled along the river to study the water quality assessment. Sites selection was made according to the implantation of human activities (domestic and agricultural). These sampling points are from upstream to downstream: Station St.1: Khanga, $36^{\circ} 40^{\prime} \mathrm{N}$ and $6^{\circ} 41^{\prime} \mathrm{E}$, a rural area, seems to be less affected by pollution than other sites; Station St.2: Errabaine, $36^{\circ} 46^{\prime} \mathrm{N}$ and $6^{\circ} 39^{\prime} \mathrm{E}$, exposed to pollution from some agricultural activities; Station St.3: Tamalous, $36^{\circ} 50^{\prime} \mathrm{N}$ and $6^{\circ} 37^{\prime} \mathrm{E}$, was selected since it is exposed to significant domestic discharges from Tamalous city; Station St.4: Kerkera, $36^{\circ} 56^{\prime} \mathrm{N}$ and $6^{\circ} 34^{\prime} \mathrm{E}, 10 \mathrm{~km}$ from the Mediterranean coast, near the village of Kerkera and exposed to pollution from urban wastewater and practices of agricultural activities; Station St.5: Telezza, 36 ${ }^{\circ} 58^{\prime} \mathrm{N}$ and $6^{\circ} 35^{\prime} \mathrm{E}$, the point of discharge in the Mediterranean, $7 \mathrm{~km}$ east of the city of Collo (Fig.-1).

\section{Field Sampling}

Waters and macroinvertebrates sampling were conducted for four months (from February to May 2017). The samples were collected on the same day, in all sites, to achieve consistency in sampling.

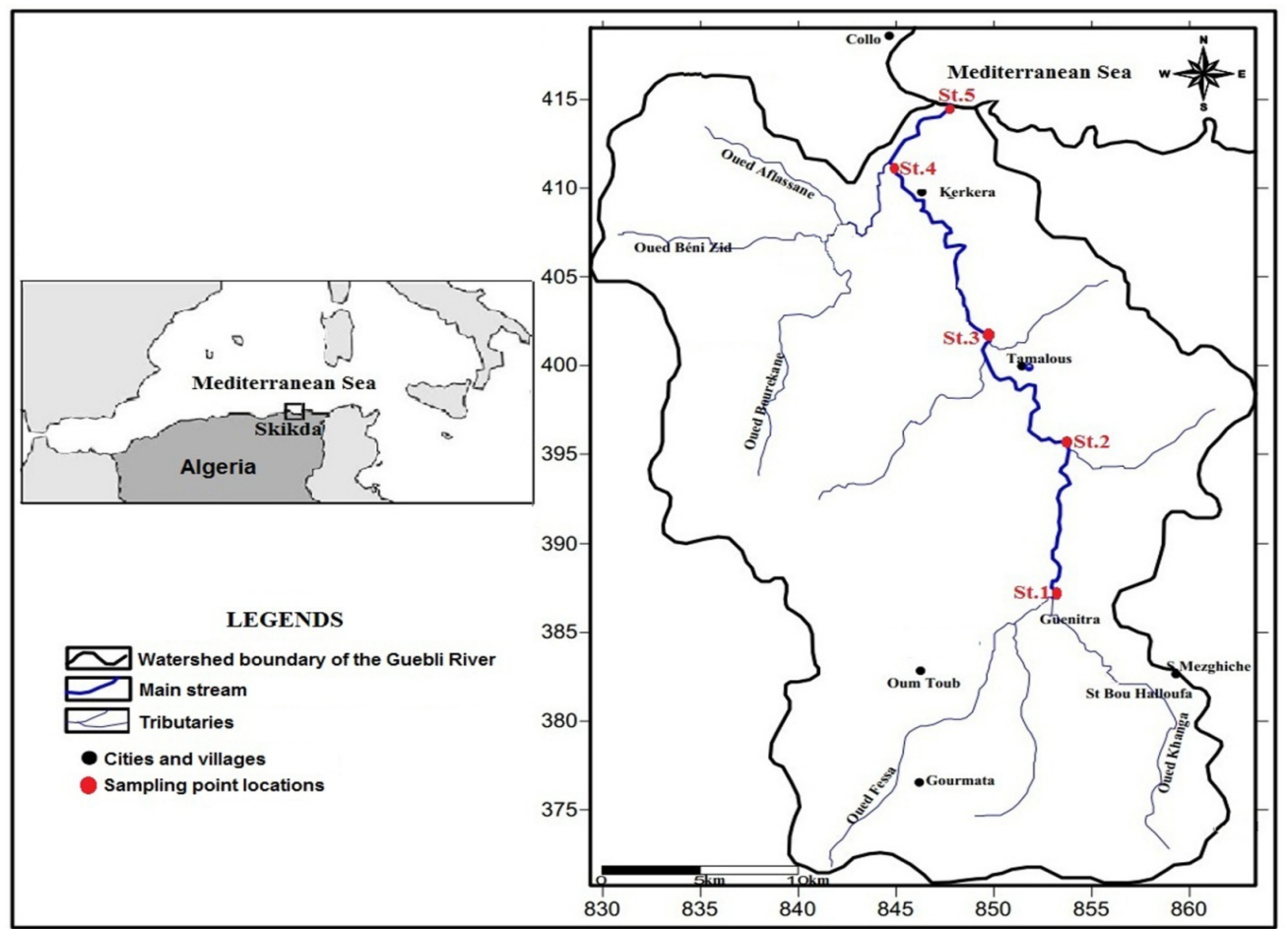

Fig.-1: Map of the Sampling Site Locations (St.1 Khanga, St.2 Errabaine, St.3 Tamalous, St.4 Kerkera, St.5 Telezza)

\section{Physicochemical Parameters and Water Quality}

For physicochemical analysis, samples of water were put in disposable plastic bottles (polyethylene). These bottles were rinsed with sampled water and the samples were collected securely. Bottles were sealed with proper labeling, kept in ice Box at $4^{\circ} \mathrm{C}$ and carefully transported to the laboratory. The physicochemical parameters studied are water temperature, $\mathrm{pH}$, Electrical Conductivity (EC), Turbidity, Total Hardness (TH), Total Dissolved Solids (TDS), Nitrite $\left(\mathrm{NO}_{2}{ }^{-}\right)$, Phosphate $\left(\mathrm{PO}_{4}^{-3}\right)$, Chloride $\left(\mathrm{Cl}^{-}\right)$, Calcium $\left(\mathrm{Ca}^{+2}\right)$, Chemical Oxygen Demand (COD), and Biological Oxygen Demand $\left(\mathrm{BOD}_{5}\right)$. All these 
RASĀYAN J. Chem.

Vol. 13 | No. 1 |168 - 176| January - March | 2020

parameters were determined according to standard methods. ${ }^{11}$ Various Instruments or methods used for physicochemical analysis are presented in Table-1. The temperature was measured on-site at the time of sampling. $\mathrm{pH}, \mathrm{EC}$, and TDS of the samples were measured immediately on arrival at the laboratory.

\section{Macroinvertebrate Identification and Biological Water Quality}

Benthic macroinvertebrate sampling follows a standardized protocol. ${ }^{6}$ Organisms are collected from habitats by kicking the substrate and using a $0.3 \mathrm{~mm}$ D-frame dip net for 5 minutes. The contents of the net were emptied into plastic boxes containing $70 \%$ alcohol. The boxes have been carefully closed, labeled and transported to the laboratory for sorting, identification and analysis. The contents were examined under a binocular loupe to separate the zoological groups. The different faunistic groups are counted and identified (generally to family) using standard taxonomic keys. ${ }^{12}$ The community structure of macroinvertebrates was evaluated by various biological indicators: Shannon - Wiener's diversity index $\left(H^{\prime}\right)$, taxa richness $(S)$, and total abundance $(N)$.

Table-1: Various Instruments or Methods for Parameters Analysis

\begin{tabular}{c|c|c}
\hline Parameters & Instrument/ Method of Analysis & Units \\
\hline Temperature & Thermometer & ${ }^{\circ} \mathrm{C}$ \\
\hline $\mathrm{pH}$ & $\mathrm{pH}$ meter MP220 & $\mathrm{pH}$ units \\
\hline Turbidity & Turbidity meter & $\mathrm{NTU}$ \\
\hline $\mathrm{EC}$ & Conductivity meter & $\mu \mathrm{S} / \mathrm{cm}$ \\
\hline $\mathrm{TDS}$ & Conductivity meter & $\mathrm{mg} / \mathrm{l}$ \\
\hline $\mathrm{NO}_{2}^{-}, \mathrm{PO}_{4}^{-3}$ & Spectrophotometer & $\mathrm{mg} / \mathrm{l}$ \\
\hline $\mathrm{Cl}^{-}, \mathrm{Ca}^{++}, \mathrm{TH}$, & Titrimetric method & $\mathrm{mg} / \mathrm{l}$ \\
\hline $\mathrm{BOD}$ & BDO meter & $\mathrm{mg} / \mathrm{l}$ \\
\hline $\mathrm{COD}$ & Dichromate reflux method & $\mathrm{mg} / \mathrm{l}$ \\
\hline
\end{tabular}

\section{Statistical Analysis}

For the different parameters studied we determined the minimum and the maximum. Variance analysis (One-way ANOVA; $p=0.05$ ) was used to compare the quality of water among all sites. All of these tests were performed using STATISTICA software package for Windows (version 10.01) and Microsoft excel.

\section{Physicochemical Parameters \\ Temperature}

The results obtained in our study show that the temperatures vary significantly with the progress of the season (one-way ANOVA: $\mathrm{p}=0.03$ ). Our data are marked by a maximum of $19^{\circ} \mathrm{C}$ for station 5 in May and a minimum of $13.5^{\circ} \mathrm{C}$ for station 2 in February (Fig.-2a). Similar findings have been observed in other work in Bounamoussa River waters in Northeast of Algeria. ${ }^{13}$ The recorded temperatures are lower compared to the maximum permissible limit $\left(25^{\circ} \mathrm{C}\right)$ of the World Health Organization. ${ }^{14}$ These measured temperatures reflect the influence of climate and season indicating a thermal balance between water and atmosphere. ANOVA analysis revealed that no significant differences in temperature values between the 5 studied stations (Table-2).

\section{pH}

The $\mathrm{pH}$ is considered to be one of the most important parameters of water quality. In most natural waters, the $\mathrm{pH}$ is usually between 6 and 8.5, while in warm waters, it is between 5 and $9 .{ }^{14} \mathrm{Our} \mathrm{pH}$ values are within the normal limits, ranging between 6.82 and 7.72 (Fig.-2b). Also, our $\mathrm{pH}$ levels are almost similar to those obtained in Bounamoussa River which varied between 6.94 and 8.02. ${ }^{13}$ The results of variance analysis showed a statistical difference among the five stations (Table-2).

\section{Electrical Conductivity (EC)}

The EC values ranged from $721 \mu \mathrm{S} / \mathrm{cm}$ in station 4 in April to $1895 \mu \mathrm{S} / \mathrm{cm}$ for station 2 in May (Fig.-2c). These levels are lower than those found in water from Bounamoussa River which is higher than 4100 
RASĀYAN J. Chem.

Vol. 13 | No. 1 | 168 - 176| January - March | 2020

$\mu \mathrm{S} / \mathrm{cm} .{ }^{13}$ Our results show that EC values do not exceed the permissible limit $(1500 \mu \mathrm{S} / \mathrm{cm})^{14}$ set for drinking water, except samples from stations 2 and 5 , therefore we can consider that these last stations are highly mineralized. The highest values recorded at St.2 and St.5 are explained by the high chloride $\left(\mathrm{Cl}^{-}\right)$ concentration (Fig.-2h) since they find that these two parameters, conductivity and chlorides, are highly correlated and evolve in parallel. ${ }^{15}$ ANOVA analysis showed a very significant difference in electrical conductivity between the 5 stations studied (Table-2).

\section{Turbidity}

The turbidity of water is related to suspended and colloidal matters such as clay and silt. For water safety, turbidity must be maintained below 5 NTU. ${ }^{14}$ Most surface waters have high turbidity and consumption directly is impossible. They need to be clarified, either by decantation, by adding a coagulant, by filtering or by a combination of these different processes. ${ }^{11}$ The turbidity analysis in our study shows that the values at St.5 are the highest while the lowest values are recorded at St.1 (Fig.-2d). These values show a slight gradient increasing from upstream to downstream (Table-2). Moreover, our results confirm that the turbidity has a passable to poor quality (according to WHO standards). ${ }^{14}$ These high values are due to the high presence of organic and inorganic materials such as silt and sediment.

\section{Total Dissolved Solids (TDS)}

TDS is determined to measure the amount of solids dissolved in water. Higher TDS values can be toxic to aquatic life. Total Dissolved Solids in this study ranged from $341 \mathrm{mg} / \mathrm{l}$ for St.4 in April to $930 \mathrm{mg} / \mathrm{l}$ for St.2 in May (Fig.-2e). Our TDS values are lower compared to those in the Seybouse River (NE of Algeria) which are between 900 and $1000 \mathrm{mg} / 1 .{ }^{16}$ Our values of TDS, especially those from St.2 and St.5, exceed the maximum permissible limits of WHO for the drinking purpose. ${ }^{14}$ Higher values of TDS in our samples might be owing to domestic discharges from urban areas, to agricultural and other human activities at and around the river. Higher TDS values may also be due to the type of soil through which water flows. ${ }^{17}$ ANOVA analysis showed a very significant difference in Total Dissolved Solids between the 5 stations (Table-2).

\section{Total Hardness (TH)}

Total Hardness is related to the level of calcium and magnesium in water. ${ }^{11}$ When the TH level is higher than $300 \mathrm{mg} / \mathrm{l}$, the nature of the waters is extremely hard. ${ }^{18}$ The total hardness from our samples ranged from $80 \mathrm{mg} / 1$ for St. 1 in May to $610 \mathrm{mg} / 1$ for St.5 in April (Fig.-2f). The results obtained show that water in St. 5 can be categorized as very hard because TH concentrations exceed the norm. Total hardness in St.5 exceeds results obtained in the Seybouse River. ${ }^{16}$ The total hardness values show a slight gradient increasing from upstream to downstream (Table-2). The highest amount of TH in the water recorded in St.5 was due to the presence of high content of calcium and probably magnesium in the water.

\section{Calcium $\left(\mathrm{Ca}^{+2}\right)$}

The monthly variation of $\mathrm{Ca}^{+2}$ recorded in this study is marked by a maximum of $233 \mathrm{mg} / \mathrm{l}$ for St.5 in May and a minimum of $56 \mathrm{mg} / 1$ for St. 1 in February (Fig.-2g). Our calcium concentrations are lower compared to those obtained in the Seybouse River which is characterized by a minimum of $84.67 \pm 14.13$ $\mathrm{mg} / 1 .{ }^{16}$ The calcium levels are mostly below the maximum acceptable concentration $(200 \mathrm{mg} / \mathrm{l})^{14}$ for drinking water with the exception of St.5. Calcium concentrations varied significantly among the 5 stations studied (Table-2).

\section{Chlorides ( $\left.\mathrm{Cl}^{-}\right)$}

The chloride concentration serves as an indicator of pollution by sewage. Water that is too rich in chloride is laxative and corrosive. ${ }^{19}$ The concentration of chlorides in the water also depends on the terrain that is crossed. The values of $\mathrm{Cl}^{-}$obtained through the present study ranged from $28.4 \mathrm{mg} / \mathrm{l}$ for St.1 during May to $177.5 \mathrm{mg} / \mathrm{l}$ for St.5 during March (Fig.-2h). Our chlorides levels are similar to those obtained in the Seybouse River. ${ }^{16}$ Compared with the water quality standards, ${ }^{14}$ our waters correspond to good quality 
RASĀYAN J. Chem.

Vol. 13 | No. 1 |168 - 176| January - March | 2020

$\left(\mathrm{Cl}^{-}<250 \mathrm{mg} / \mathrm{l}\right)$. ANOVA analysis showed a very significant difference in chlorides concentrations between the five stations studied (Table-2).

\section{Nitrites $\left(\mathrm{NO}_{2}^{-}\right)$}

Nitrites come from incomplete oxidation of organic matter. Like nitrates, nitrites are highly present in a large part of the waters. ${ }^{20}$ The presence of a high level of nitrite in water is an indicator of wastewater pollution. ${ }^{21}$ The values of $\mathrm{NO}_{2}{ }^{-}$recorded in this study ranged from $0.02 \mathrm{mg} / 1$ for St.4 in May to $0.17 \mathrm{mg} / 1$ for St.2 in March (Fig.-2i). Similar findings have been observed in other works in Northeastern Algeria. ${ }^{22}$ According to WHO standards, our water corresponds to good quality $\left(\mathrm{NO}_{2^{-}} \leq 0.2 \mathrm{mg} / \mathrm{l}\right) .{ }^{14}$ The results of the ANOVA analysis showed a very significant difference in nitrites concentrations between stations (Table-2).

\section{Phosphate $\left(\mathrm{PO}_{4}{ }^{-3}\right)$}

The presence of phosphates in natural waters with concentrations above $0.2 \mathrm{mg} / 1$ indicated pollution by synthetic detergents, as well as by runoff water. ${ }^{23}$ The monthly variation of $\mathrm{PO}_{4}^{-3}$ recorded in this study is marked by a maximum of $1.10 \mathrm{mg} / 1$ for station 5 in March and a minimum of $0.01 \mathrm{mg} / 1$ for station 2 in May (Fig.-2j). Levels of phosphate in the Guebli River are similar to those obtained in the Djendjen River (NE of Algeria). ${ }^{22}$ Compared with the WHO standards $\left(\mathrm{PO}_{4}{ }^{-3}<0.1 \mathrm{mg} / \mathrm{l}\right),{ }^{14}$ most of the samples correspond to poor quality waters (Fig.-2j). No variation in phosphate concentrations was observed between stations (Table-2).

\section{Chemical Oxygen Demand (COD)}

The importance of COD can be translated by the amount of oxidizable organic matter that is not biologically degraded by microorganisms. ${ }^{18}$ The variation recorded for the COD is marked by a maximum of $45 \mathrm{mg} / \mathrm{l}$ for station 5 . The values recorded for the other stations are less than $30 \mathrm{mg} / \mathrm{l}$ (Fig.-2k). This COD level is very lower compared to those found in the Seybouse River with a mean value of $546.8 \pm 352.1 \mathrm{mg} / 1 .{ }^{16}$ Except the station 5, the COD values do not exceed the value of $40 \mathrm{mg} / 1 \mathrm{set}$ by the WHO standards for water quality, which allows these waters to be classified as good quality. The results of the ANOVA analysis showed a very significant difference in COD concentrations between the 5 stations studied (Table-2).

\section{Biochemical Oxygen Demand $\left(\mathrm{BOD}_{5}\right)$}

$\mathrm{BOD}_{5}$ represents the level of oxygen used by bacteria to partially decompose or completely oxidize biochemical materials in water and which constitute their carbon source (fats, carbohydrates, surfactants, etc.). ${ }^{11}$ The values of $\mathrm{BOD}_{5}$ recorded during this study ranged from $4 \mathrm{mg} / \mathrm{l}$ for station 1 during the month of April to $49 \mathrm{mg} / \mathrm{l}$ for station 5 during the same month (Fig.-2l). A high value of $\mathrm{BOD}_{5}$ suggesting the high quantity of organic pollutants in the aquatic environments. ${ }^{11}$ Our levels of $\mathrm{BOD}_{5}$ are higher than those reported in the Djendjen River ${ }^{22}$ but similar to those in the Seybouse River. ${ }^{16}$ Compared to the WHO drinking water standard which should not exceed $6 \mathrm{mg} / 1$, our $\mathrm{BOD}_{5}$ results allow river water to correspond to poor and very poor quality. The presence of a high amount of $\mathrm{BOD}_{5}$ in water clearly indicated pollution which may be due to domestic sewage in the water. The results of the ANOVA analysis showed a significant difference in $\mathrm{BOD}_{5}$ concentrations between the five stations studied (Table2). High concentration of Calcium $\left(\mathrm{Ca}^{+2}\right)$, Chlorides $\left(\mathrm{Cl}^{-}\right)$, Nitrites $\left(\mathrm{NO}_{2}^{-}\right)$, Phosphate $\left(\mathrm{PO}_{4}^{-3)}, \mathrm{COD}\right.$ and $\mathrm{BOD}_{5}$ in station 5 are due to the accumulation of agricultural fertilizers, organic wastes, sewage discharge, and livestock production facilities in the downstream of the river and to the possibility of contacts with water of marine origin for chlorides. ${ }^{24}$

\section{Macroinvertebrates}

\section{Structure of the Macroinvertebrates Community}

The faunistic inventory of the Gubli River includes 09 orders of benthic invertebrates divided into 18 families. Diptera is the richest group in taxa. They are dominated by two families: Chironomidae and Culicidae. Nematoda and Ephemeroptera are in second and third place respectively. The Ephemeroptera 
RASĀYAN J. Chem.

Vol. 13 | No. 1 |168 - 176| January - March | 2020

are dominated by the Ephemeridae family. The Trichoptera and the Plecoptera occupied the fourth and fifth place. The Coleoptera, Odonata, Gastropoda and Hemiptera represent $1.56 \%$ of benthic fauna collected in the watercourse (Fig.-3).

Table-2: Variation of Water Physicochemical Parameters According to the Sampling Sites (one-way ANOVA: Site)

\begin{tabular}{c|c|c|c}
\hline Parameters & df & F & P-value \\
\hline $\mathrm{T}(\mathrm{C})$ & 4 & 0.23 & 0.91 \\
\hline $\mathrm{pH}$ & 4 & 3.34 & 0.038 \\
\hline $\mathrm{EC}(\mu \mathrm{S} / \mathrm{cm})$ & 4 & 22.13 & $<10^{-3}$ \\
\hline Turbidity $(\mathrm{NTU})$ & 4 & 4.05 & 0.019 \\
\hline $\mathrm{TDS}(\mathrm{mg} / \mathrm{l})$ & 4 & 20.41 & $<10^{-3}$ \\
\hline $\mathrm{TH}(\mathrm{mg} / \mathrm{l})$ & 4 & 3.18 & 0.044 \\
\hline $\mathrm{Ca}^{+2}(\mathrm{mg} / \mathrm{l})$ & 4 & 11.41 & $<10^{-3}$ \\
\hline $\mathrm{Cl}^{-}(\mathrm{mg} / \mathrm{l})$ & 4 & 11.15 & $<10^{-3}$ \\
\hline $\mathrm{NO}_{2}^{-}(\mathrm{mg} / 1)$ & 4 & 12.02 & $<10^{-3}$ \\
\hline $\mathrm{PO}_{4}^{-3}(\mathrm{mg} / \mathrm{l})$ & 4 & 0.99 & 0.44 \\
\hline $\mathrm{COD}^{(\mathrm{mg} / \mathrm{l})}$ & 4 & 26.61 & $<10^{-3}$ \\
\hline $\mathrm{BOD}_{5}(\mathrm{mg} / \mathrm{l})$ & 4 & 6.24 & $<10^{-2}$ \\
\hline
\end{tabular}

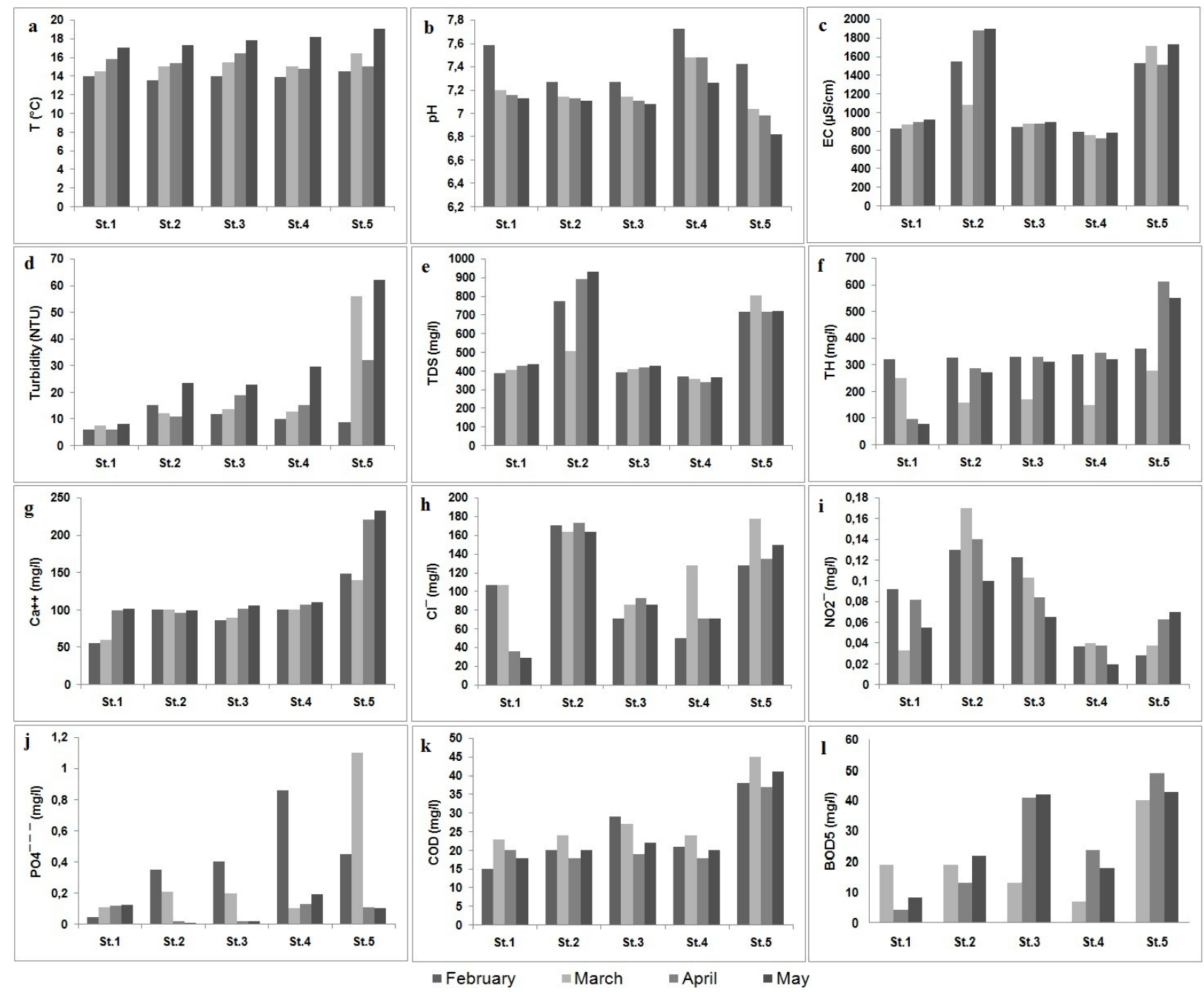

Fig.-2: Spatiotemporal Variation of Water Quality in the Guebli River between February and May 2017 
RASĀYAN J. Chem.

Vol. 13 | No. 1 | 168 - 176| January - March | 2020

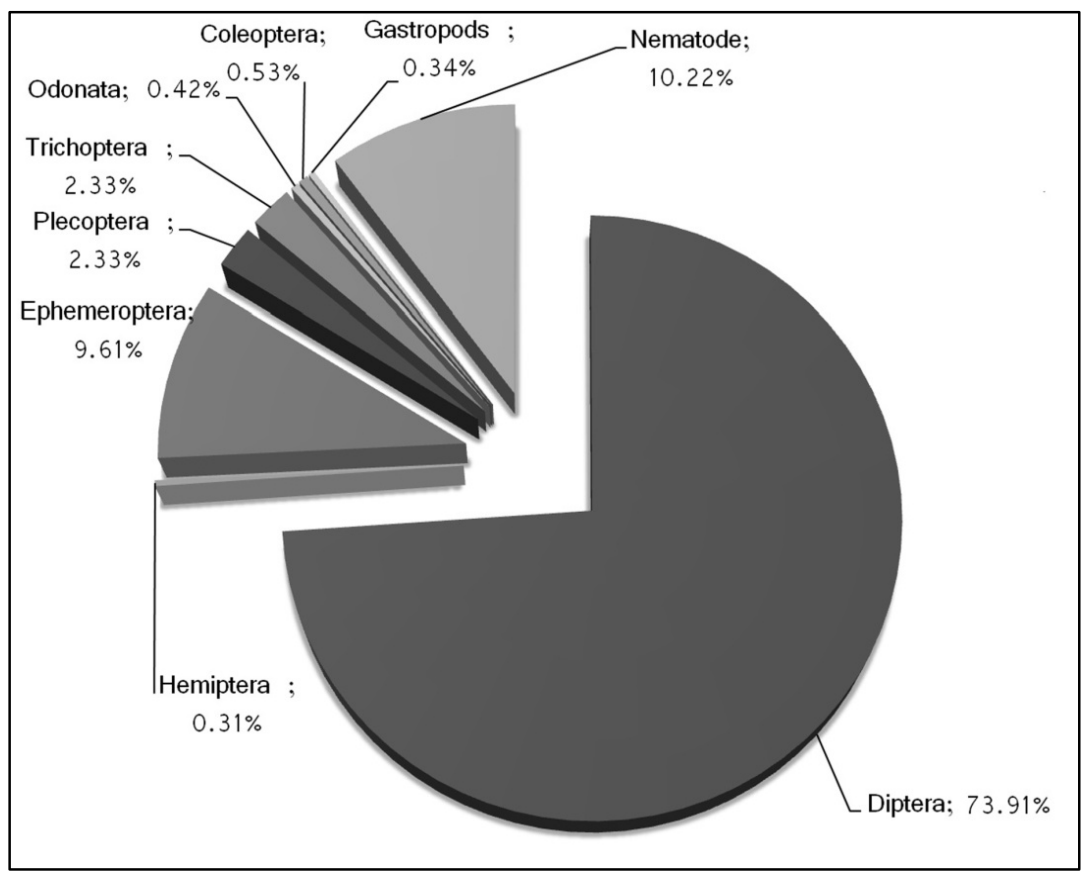

Fig.-3: Taxonomic Composition of Macroinvertebrate Community in the Guebli River

\section{Macroinvertebrate Community Metrics}

2992 individuals of macroinvertebrates from 18 families were collected and identified in all study sites. This abundance fluctuates with the station, ranging from 80 individuals for station 1 in February to 215 individuals for station 5 in May (Fig.-4). In general, the variation in biological indicators of the macroinvertebrate community between sites could be attributed to the physicochemical water quality. The values of $(\mathrm{S})$ and $\left(\mathrm{H}^{\prime}\right)$ are higher at the slightly polluted site (St.1) compared to the most polluted site (St.5). In accordance with these results, pollution-sensitive species (e.g. Ephemeroptera, Plecoptera and Trichoptera $)^{25}$ were highly abundant at St.1 compared to St.5. At station 5, the species, which tolerate a wide range of environmental conditions (e.g. Diptera, Hemiptera and Gastropod), were more abundant. Diptera which are highly resilient and resistant to pollution organisms (Pollution-Tolerant) were the most present especially in station 5 . These results support the idea of a highly polluted environment. ${ }^{26}$

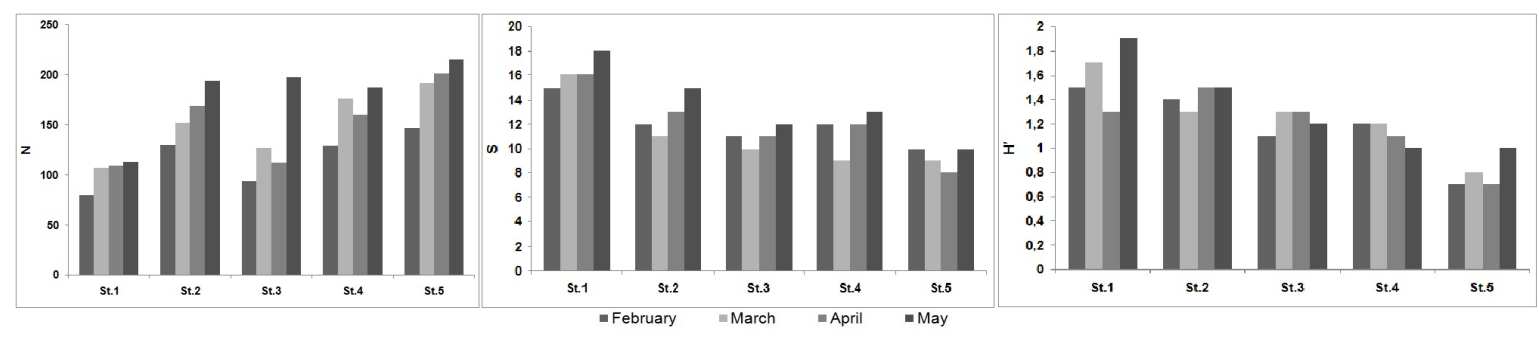

Fig.-4: Biological Indicators of Macroinvertebrate Community for Each Sampling Site between February and May 2017 (N= Total Abundance, S= Taxa Richness and H'= Shannon - Wiener's Diversity Index)

\section{CONCLUSION}

Different physicochemical and biological parameters are employed to determine the water quality of the Guebli River. The present study showed that water samples from the downstream station (St.5) were very poor in quality compared to other water samples. Several levels of the physicochemical parameters studied in station 5 were above the concentrations permitted by the World Health Organization standards for drinking water. This pollution may be due to agricultural runoff and wastewater from various local 174 
activities. The study also shows that the Macroinvertebrate community composition varies with the quality of water in the river with better quality metrics in the least polluted stations. Finally, this accumulation of pollutants can be dangerous for both aquatic and human life, therefore, to avoid this risk in the Guebli River, permanent controls must be regulated soon and urban discharges shall be subject to treatment before entering the river course.

\section{ACKNOWLEDGMENT}

We are grateful to the authorities of the Water Quality Control Laboratory of the Algerian Water Company in Skikda for laboratory analyzes.

\section{REFERENCES}

1. R. Jean-Claude, L'eau source de vie, éditions BRGM, France, p. 01, 23 (1998)

2. B. Lehner, C. Reidy Liermann, C. Revenga, C. Vorosmarty, B. Fekete, P. Crouzet, P. Doll, M. Endejan, K. Frenken, J. Magome, C. Nilsson, J.C. Robertson, R. Rodel, N. Sindorf and D. Wisser, Frontiers in Ecology and the Environment, 9(9), 502(2011), DOI: 10.1890/100125

3. J. Margat, S. Treyer, L'eau des méditerranéens: situation et perspectives. Plan Bleu PNUE/PAM, Technical Report Series no. 158, Athens, Greece (2004)

4. L. Zella, L'eau pénurie ou incurie, Edition Office des Publications Universitaires, Algiers, p. 12, 27 (2017)

5. J.P. Thomas, Ph. D. Thesis, Department of Vegetal Ecology, University of Montpellier, Montpellier, France (1975)

6. M.T. Barbour, J. Gerritsen, B.D. Snyder and J.B. Stribling, Rapid Bioassessment Protocols for Use in Streams and Wadeable Rivers: Periphyton, Benthic Macroinvertebrates and Fish, Second Edition EPA 841-B-99-002, U.S. Environmental Protection Agency, Washington, D. C. (1999)

7. B.Z. Pan, Z.Y. Wang and M.Z. Xu, River Research and Applications, 28, 1149(2012), DOI: 10.1002/rra. 1515

8. D. Serpa, J.J. Keizer, J. Cassidy, A. Cuco, V. Silva, F. Gonçalves, M. Cerqueira and N. Abrantes, Environmental Science: Processes \& Impacts, 16, 1434(2014), DOI: 10.1039/c3em00488k

9. B. Genin, C. Chauvin and F. Menard, Cours d'eau et indices biologiques: pollution et méthodes IBGN, Edition ENESAD-CNERTA, Dijon, p. 140, 173 (1997)

10. I. Mecibah, Ph. D. Thesis, Department of Hydrogeology, University of Badji Mokhtar, Annaba, Algeria (2017)

11. J. Rodier, L. Bernard and M. Nicole, L'Analyse de l'eau, $9^{e}$ édition, dunod, Paris, p. 10, 92 (2009)

12. H. Tachet, M. Bournaud and P.H. Richoux, Introduction à l'étude des Macroinvertébrés des eaux douces, Report of Lyon 1 University and French Association of Limnology, Lyon, France, (1980)

13. H. Ramdani and A. Laifa, Journal of Water and Land Development, 35, 185(2017), DOI: 10.1515/jwld-2017-0083

14. WHO Guidelines for Drinking Water Quality, World Health Organization, Vol.1, 3rd Edn., WHO, Geneva Recommendation (2004)

15. H. Guevara, C. Green-Ruíz, J. Herrera-Barrientos, O. Escolero-Fuentes, O. Delgado-Rodríguez, S. Belmonte-Jiménez and M. Ladrón de Guevara, Cienciae Investigación Agraria, 39, 229(2012), DOI: $10.4067 /$ S0718-16202012000100020

16. M. Guettaf, A. Maoui and Z. Ihdene, Applied Water Science, 7, 295(2017), DOI:10.1007/s13201$014-0245-\mathrm{Z}$

17. K. Karthik, R. Mayildurai, R. Mahalakshmi and S. Karthikeyan, Rasayan Journal of Chemistry, 12(2), 409(2019), DOI:10.31788/RJC.2019.1225005

18. E. Humbert and P. Pommier, Revue du Syndicat National des Vétérinaires Inspecteurs du Ministère de l'Agriculture français, 100, 369(1988)

19. M. Bengoumi, A. Traoure, N. Bouchriti, D. Bengoumi and A. El Haraiki, Revus d'information scientifique et technique, 3, 5(2004)

20. F. Fekrache and K. Boudeffa, Rasayan Journal of Chemistry, 12(2), 827(2019), DOI: 10.31788/RJC.2019.1225223

21. A. Krika and F. Krika, Pollution, 3(2), 261(2017), DOI: 10.7508/pj.2017.02.008 
RASĀYAN J. Chem.

Vol. 13 | No. 1 |168 - 176| January - March | 2020

22. J. Verneaux, Ph. D. Thesis, Department of natural science, University of Franche Comté, Besançon, France (1973)

23. D. Kumar, V. Kumar and S. Kumari, Rasayan Journal of Chemistry, 11(4), 1477(2018), DOI: 10.31788/RJC.2018.1143075

24. S.A. Al-Shami, C.S.M. Rawi, A.H. Ahmad, S.A. Hamid and S.A. Nor, Ecotoxicology and Environmental Safety, 74, 1195(2011), DOI: 10.1016/j.ecoenv.2011.02.022

25. A. Beyene, T. Addis, D. Kifle, W. Legesse, H. Kloos and L. Triest, Ecological Indicators, 9, 381(2009), DOI: $10.1016 /$ j.ecolind.2008.05.001

[RJC-5255/2019] 